\title{
Wind-Conditioned 20th Century Decline of Birch Treeline Vegetation in the Swedish Scandes
}

\author{
LEIF KULLMAN ${ }^{1}$
}

(Received 14 September 2004; accepted in revised form 22 February 2005)

\begin{abstract}
The study focused on a frequent, although not dominant, mode of treeline change in the Swedish Scandes over the past century. Monitoring of stand density decline in a wind-exposed subalpine birch (Betula pubescens ssp. tortuosa) population was carried out over the past 30 years. The overall result included substantial and unbalanced individual mortality and a drastic reduction in stature of surviving birches. Radiocarbon dating of in situ subfossil birch-tree remains in an adjoining but windier site revealed complete stand demise over the past century or so. It is inferred that the extant and extinct birch populations represent different phases in an unbroken process of stand-level demise, hypothetically initiated in response to reindeer disturbance during the final phase of the Little Ice Age. This process was subsequently communicated more or less autogenically in a leeward direction as a consequence of the exposed and drought-prone nature of the site. Increasing westerly wind circulation and decreasing soil moisture (earlier snowmelt) during the past century may have contributed in this respect, although these aspects require further study. Within strongly wind-exposed terrain, a century of substantial warming has not sufficed to offset the birch decline. The results highlight the conclusion that under certain circumstances, wind and associated ecological and physiological effects are the overriding determinants of treeline position and structure. These are fundamental insights for generating realistic landscape-scale models of treeline change in a hypothetically warmer future.
\end{abstract}

Key words: Betula pubescens ssp. tortuosa, deflation, drought, models, reindeer, retrogression, Swedish Scandes, treeline, warming, wind

RÉSUMÉ. Cette étude porte sur un mode fréquent, bien que non dominant, de changement de la limite des arbres dans les Scandes suédoises au cours du siècle précédent. Durant les 30 dernières années, on a suivi le déclin dans la densité d'un peuplement de bouleaux pubescents subalpins (Betula pubescens ssp. tortuosa) qui étaient exposés au vent. Le résultat global comprenait une importante mortalité individuelle non compensée ainsi qu'une baisse radicale dans la taille des bouleaux survivants. La datation au radiocarbone de restes subfossiles de bouleaux trouvés in situ dans un lieu voisin mais plus venteux a révélé qu'un peuplement s'était complètement effondré au cours du siècle dernier ou à peu près. On en déduit que les peuplements de bouleaux existants et disparus représentent différentes phases d'un processus ininterrompu d'effondrement du niveau de peuplement, qui aurait son origine dans la perturbation causée par le renne durant l'ultime phase du petit âge glaciaire. Ce processus s'est ensuite poursuivi de façon plus ou moins autogène dans la direction du vent en raison de la nature du site qui était exposé au vent et à la sécheresse. Un accroissement de la circulation du vent d'ouest et une diminution de l'humidité du sol (fonte des neiges précoce) au cours du siècle dernier pourraient avoir été des facteurs contributifs, bien que cela demande une étude plus approfondie. Sur un terrain très exposé au vent, un siècle de réchauffement important n'a pas été suffisant pour neutraliser le déclin du bouleau. Les résultats soulignent la conclusion à savoir que, dans certaines circonstances, le vent et les effets écologiques et physiologiques connexes sont les facteurs primordiaux qui déterminent la position et la structure de la limite des arbres. Ce sont là des connaissances fondamentales pour la création de modèles du changement de la limite des arbres, modèles réalistes à l'échelle du paysage, dans un avenir en réchauffement.

Mots clés: Betula pubescens ssp. tortuosa, déflation, sécheresse, modèles, renne, rétrogression, Scandes suédoises, limite des arbres, réchauffement, vent

Traduit pour la revue Arctic par Nésida Loyer.

\section{INTRODUCTION}

In the Swedish Scandes, climate warming $\left(1^{\circ} \mathrm{C}\right.$ over the 20th century) has evoked upward shifts of the treeline as great as 150-165 m at some sites (Kullman, 2001, 2004d). This process is quantitatively paralleled elsewhere in the
Northern Hemisphere (Kremenetski et al., 1999; Meshinev et al., 2000; Butler and Dechano, 2001; Munroe, 2003) as a plausible manifestation of broad-scale climate change. Obviously for the same reason, emergence of new stems within the advance zone (between the old and new treelines) is now a conspicuous process in many instances (Butler

\footnotetext{
${ }^{1}$ Physical Geography, Department of Ecology and Environmental Science, Umeå University, S-901 87 Umeå, Sweden; leif.kullman@eg.umu.se

(C) The Arctic Institute of North America
} 
and Dechano, 2001; Kullman, 2001, 2004d; Lloyd and Fastie, 2003). Notably, however, most sites display upward treeline shifts smaller than those cited above, or no shifts at all (Kullman, 1979, 2001). Apparently, treeline positions (m a.s.l.) and structures are site-specifically constrained and modulated by different combinations of local and regional climatic forcing agents. Such mechanisms warrant closer investigation. Likely candidates for such agents relate to topoclimatic features such as strong wind action, extreme snow, and soil conditions. The current operational efficiency of this complex of agents is highlighted by the existence of patches within the treeline ecotone with actively regressing or totally denuded tree cover, ground vegetation, and topsoils, typically on windward sites of minor hillocks. Recent recolonizations by trees or other plants are virtually lacking and seem to be prohibited by local climatic harshness and associated deficiency of soil moisture and essential nutrients. Although these features are only minor parts of the total treeline landscape, they were already being observed frequently in the treeline ecotone more than 30 years ago (Kullman, 1997). They contrasted sharply with the $75-100 \mathrm{~m}$ elevational advance of the nearby birch treeline since the early 20th century and infilling of birch stands in more sheltered positions (Kullman, 1979). Over the past century, these regressive phenomena have been more or less explicitly described in the scientific literature (e.g., Sernander, 1905; Lundqvist, 1948; Rudberg, 1968; Holtmeier et al., 2003, 2004) from various parts of the Fennoscandian treeline landscape. In fact, processes of this kind seem to have more general relevance in alpine and Arctic regions with a more or less oceanic climate (e.g., Robertson, 1993; Grishin et al., 1996), but occasionally also in more continental regimes (Holtmeier et al., 2004).

In the perspective of the past century's well-documented warming (all seasons) in northern Sweden (Alexandersson, 2002), regressive processes of this kind may seem counterintuitive (cf. Grace et al., 2002), and their full comprehension presupposes a historical approach to the analysis. The present study seeks to contribute to a more complete understanding of this particular facet of treeline evolution by analyzing and monitoring the recent and subrecent history of arboreal vegetation in a typical retrogressional patch in the subalpine birch forest belt. Comprehension of this issue is essential for generation of realistic and detailed landscape-scale models of treeline and mountain woodland evolution in a world expected to warm beyond historic precedence during the next 100 years (IPCC, 2001; Räisänen et al., 2004).

\section{STUDY AREA}

The study was carried out in the southern Swedish Scandes, province of Jämtland (Fig. 1). A site representative of the processes focused on was located on the lower
E-facing slope of Mt. Storsnasen (Fig. 2). This mountain reaches $1463 \mathrm{~m}$ a.s.l., with the adjacent floor of the Handölan River valley around $670 \mathrm{~m}$ a.s.l. The nearest meteorological station is Storlien/Visjövalen at $642 \mathrm{~m}$ a.s.l. and about $20 \mathrm{~km}$ to the northwest. The region's moderately oceanic and humid climate is due to its proximity to the Atlantic Ocean and the existence of low passes in the west. Mean temperatures $(1961-90)$ are $-7.6^{\circ} \mathrm{C}$ for January, $10.7^{\circ} \mathrm{C}$ for July, and $1.1^{\circ} \mathrm{C}$ for the year. On a yearly basis, the predominant wind direction is westerly (30\%), which at the study site manifests as strong downslope winds (Kullman, 1979). The most frequent winds are $\mathrm{W}-\mathrm{S}$ in winter and $\mathrm{W}-\mathrm{NW}$ in summer (Raab and Vedin, 1995). Mean annual precipitation totals $850 \mathrm{~mm}$ for the same period. The bedrock of amphibolites is well covered by glacial till and peat up to or slightly above the birch treeline.

Climate warming in all seasons has characterized the past century. The summer period (June-August) has warmed by about $0.1^{\circ} \mathrm{C}$ per decade. Of all seasons, spring (March-May) shows the most consistent temperature rise $\left(0.15^{\circ} \mathrm{C}\right.$ per decade $)$, which implies earlier snowmelt and onset of the growth period (Alexandersson, 2002). Drying-out of alpine/subalpine soils is a general consequence (Kullman, 2004a and literature cited therein).

The local treelines (the upper limit of $2 \mathrm{~m}$ high trees) are positioned at $800 \mathrm{~m}$ a.s.l. for mountain birch (Betula pubescens Ehrh. ssp. tortuosa (Ledeb.) Nyman), $720 \mathrm{~m}$ a.s.l. for pine (Pinus sylvestris L.), and $820 \mathrm{~m}$ a.s.l. for spruce (Picea abies (L.) Karst). The forest-alpine tundra transition (treeline ecotone) is dominated by mountain birch woodland, interspersed with patches of treeless alpine tundra and mires that increase in size and coalesce as altitude increases.

\section{MATERIALS AND METHODS}

Three plots were used to examine a sequence of birch decline (Fig. 2). In 1972, a $10 \times 10 \mathrm{~m}$ permanent monitoring plot (Plot A) was established on the $\mathrm{W}$-facing flank of a small hillock within the major E-facing slope of Mt. Storsnasen ( $725 \mathrm{~m}$ a.s.1., $\left.63^{\circ} 13^{\prime} \mathrm{N} ; 12^{\circ} 24^{\prime} \mathrm{E}\right)$. The plot has an elevational amplitude of about $5 \mathrm{~m}$ and is exposed towards prevailing westerly winds. It was placed in a representative portion of a local mountain birch stand that seemed to be in a stage of active demise and frontal retraction. The edge of more or less dying trees coincides with variously distinct wind deflation scars encroaching into the intact vegetation and soil cover (Fig. 3). The entire hillock is surrounded by a sloping and virtually treeless mire. The soil is sandy and dries rapidly during the summer since no supply of soil water from higher elevations takes place.

West of the erosion front is a treeless area, recently colonized with sparse alpine tundra, which showed evidence of strong cryoturbation (needle ice, frost heave, mud 


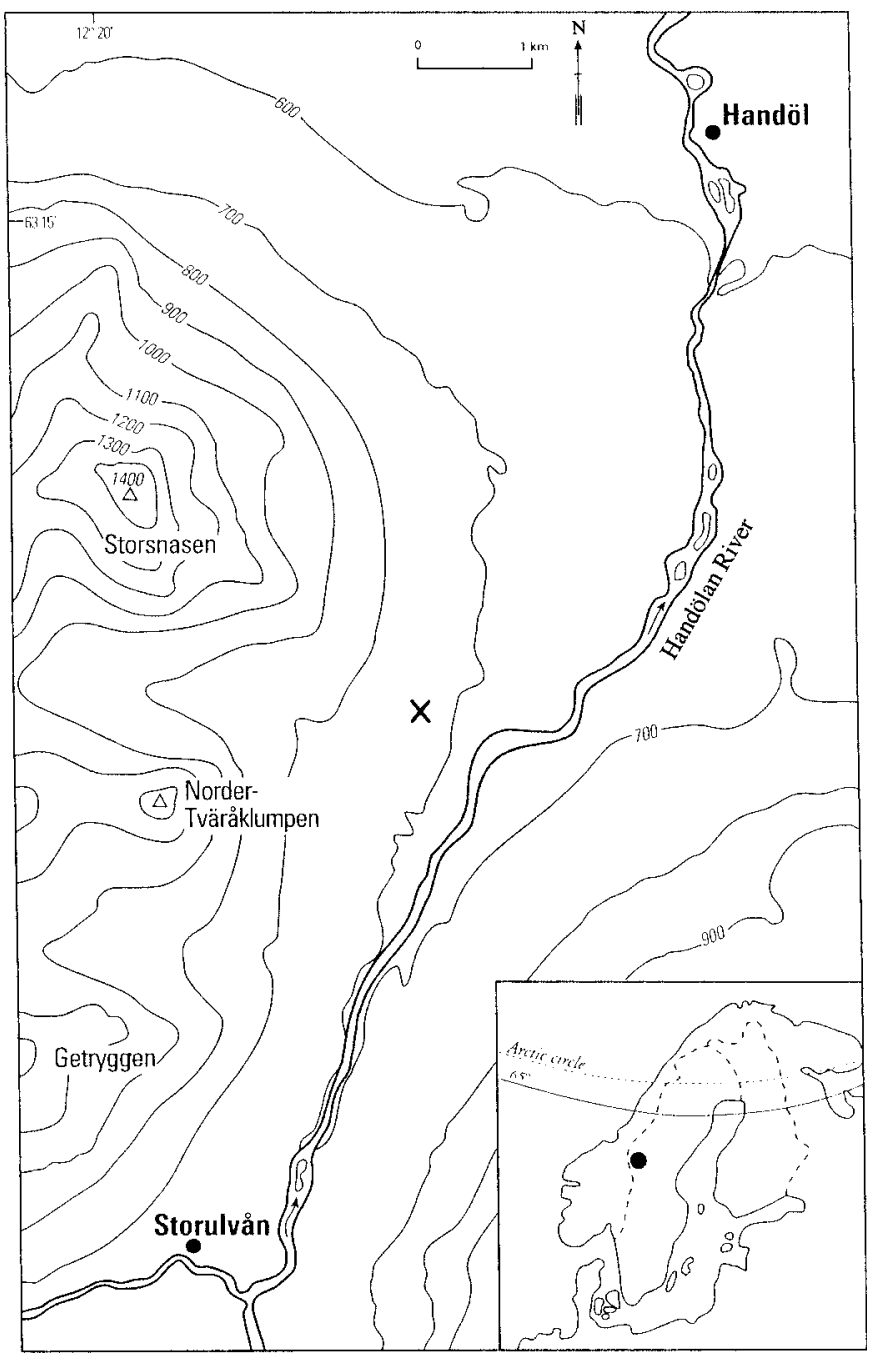

FIG. 1. Location map showing the study site (X). Contour interval is $100 \mathrm{~m}$. The current treeline of mountain birch runs slightly below the $900 \mathrm{~m}$ contour.

boils) and wind deflation of the topsoil. This area was virtually littered with in situ birch stumps in various stages of decay that clearly suggested a fairly long prehistory for the current phase of tree demise. All wood remnants that could be recovered here were sampled for radiocarbon dating within a $10 \times 10 \mathrm{~m}$ plot (Plot B) fringing the western limitation of Plot A (Fig. 2). Since all birch remnants were strongly decayed, tree rings were not discernible, which excluded dendrochronological dating.

A closed ground cover with dominant Empetrum hermaphroditum and subsidiary Betula nana, Calluna vulgaris, Vaccinium myrtillus, Deschampsia flexuosa, Pleurozium schreberi and Hylocomium splendens is also present in Plot A. In Plot B, the ground vegetation is discontinuous. Large spots display bare mineral soil, interspersed with small clones of Loiseleuria procumbens, scattered specimens of Arctostaphylos alpinus, Juncus trifidus, Carex bigelowii, Ranunculus glacialis (temporarily) and fragments of reindeer lichens (Cladina spp.).

On the somewhat steeper E-facing, lee slope of the focused hillock, a dense, vigorously growing birch stand

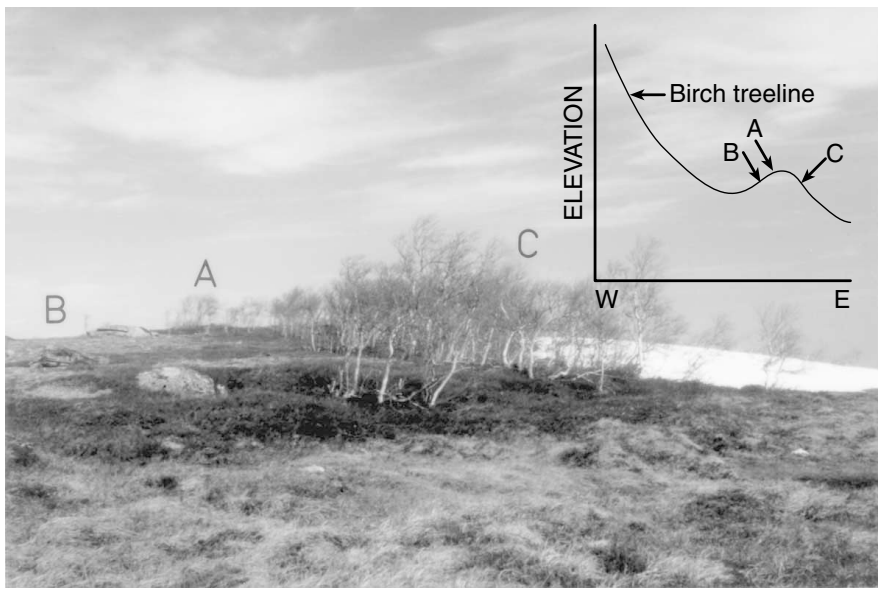

FIG. 2. The study site viewed from the south, showing the deflation area to the left (Plot B); the sparse, declining birch stand around the snow edge (Plot A); and the denser, leeward birch stand at the center (Plot C). The insert sketch shows the relative positions of Plots A, B, and C within the local topography at the lower, E-facing slope of Mt. Storsnasen. Photo: 19 April 1998.

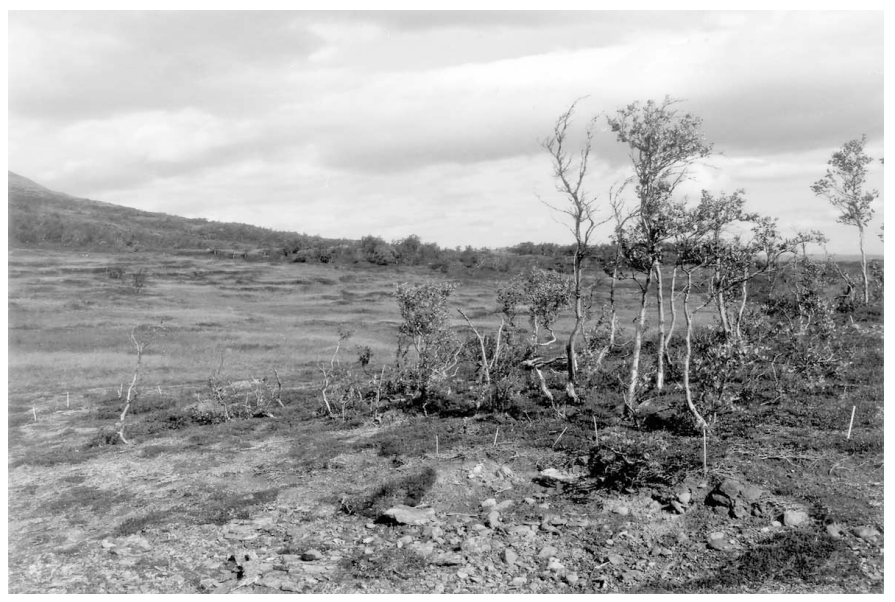

FIG. 3. View of the regressing birch population (Plot A), with birches diminishing in height from east to west. The wind-eroded surface in the foreground (Plot B) was previously treed and now encroaches on the birch stand, as measured annually from the six white sticks visible along the erosion scarp. Photo: 1 August 1996.

prevails. The predominant ground layer species is Vaccinium myrtillus. During the winter, the birch trees here are virtually buried in a $1.5-2.5 \mathrm{~m}$ deep snowdrift that usually remains until mid-June, or even longer in some years. In 2003, the age structure of this population was assessed within a $10 \times 10 \mathrm{~m}$ quadrat (Plot $\mathrm{C}$ ), by coring and sawing (trunk/root junction) all stems higher than $1 \mathrm{~m}$ (Fig. 2). Tree rings were counted in the laboratory using a stereomicroscope.

Radiometric dating of the birch remnants was carried out by the Radiocarbon Dating Laboratory in Stockholm (ST) and Beta Analytic Inc., Miami (Beta). All dates are given as radiocarbon years BP $(=$ AD 1950). The low age of most samples (all less than 250 radiocarbon years) implies that calibration to calendar years is seriously inaccurate. This relates to particularly marked fluctuations in the atmospheric ${ }^{14} \mathrm{C}$ levels since about AD 1650 
(Stuiver and Pearson, 1986). For this reason, the radiocarbon-dating laboratories report the ages in fairly broad and imprecise intervals. The presence of bark made identification to species (mountain birch) unambiguous.

In mid July 1972, all living birches within Plot A were entered on a sketch map and tallied with respect to maximum living height. On five subsequent occasions, at the same time of year in 1988, 1995, 2001, and 2003, the individual birches were located again and re-measured. In addition, we carefully scrutinized the plot for emergence of new birch recruits. These data provide the basis for evaluation of 31 years of demographic and size evolution.

Since late June 1996, ground temperature measurements within the central part of plot A have been carried out regularly (about once a month), using three soil temperature probes (resistance thermistors of the brand TO-03R) with the sensors installed at the interface between organic and mineral soil. At this depth $(25 \mathrm{~cm})$, short-term fluctuations are damped, and the current readings should quite accurately integrate the true soil temperature regime over the same intervals (cf. Harris, 2001). Snow depth in all three plots was also assessed at the time of these measurements. All these data form parts of a more extensive monitoring program and are only summarily reported here.

Along $3 \mathrm{~m}$ of the scarp between stripped coarse gravel and intact vegetation/soil at the interface between Plots A and $\mathrm{B}$, the rate of erosion has been assessed at regular intervals since 1977. The annual retraction of this front has been monitored by measurements from six fixed sticks.

\section{RESULTS}

\section{Demography and Vitality of Declining Birch in Plot A}

During the period from 1972 to 2003, the number of living individual birches decreased from 44 to 31 (about $30 \%$ ). No recruits (genets) were recorded during the same period in plots A and B. The mean height of all individual birches decreased at a fairly constant rate from $1.78 \pm$ $0.65 \mathrm{~m}$ to $0.70 \pm 0.58 \mathrm{~m}$, a reduction of about $60 \%$. The number of tree-sized birches ( $>2 \mathrm{~m}$ tall) decreased from 22 to $1(95 \%)$. In no case have demised stems of this size-class been succeeded by equally tall basal sprouts.

Over the entire observation period, the birches have provided a conspicuous impression of low vitality, showing a multitude of dead twigs and short annual shoots. Most individuals had signs of wind deformation, such as leaning stems without twigs on the $\mathrm{W}$-facing sides of their crowns. The height of the birches diminished from east to west within the plot—-that is, against the prevailing wind direction.

\section{Radiocarbon Dates from Plot B}

A total of 36 subfossil birches were recovered and radiocarbon-dated within the treeless plot. They all appeared in situ as basal trunk/root sections, either well preserved in small, residual raw humus patches or lying more or less exposed on the bare mineral soil. In most cases, they seemed to represent quite small trees (basal diameters of $5-8 \mathrm{~cm}$ ), closely resembling the size distribution of the currently living population in Plot A. The obtained ages span somewhat less than the past 250 radiocarbon years (Table 1). Tentative calibration implies that the trees died after the 16th century and in some cases even after AD 1950. The relatively high degree of preservation of these specimens, renowned for decaying fully and rapidly if not covered by peat, may suggest that the majority date to the 20th and late 19th centuries. Further support for this view is provided by the fact that dating was carried out on entire stem cross sections, with a likely life span of at least 100 years. This implies a slight bias toward older ages for the obtained mortality dates. Table 1 illustrates a tendency for the youngest ages to cluster near the current erosion front, at the interface between Plots A and B.

\section{Current Erosion Rates}

From 1977 to 2003, the annually surveyed erosion front between intact vegetation (Plot $\mathrm{A}$ ) and denuded mineral soil (Plot B) retreated at a constant average rate of $2 \mathrm{~cm}$ per year, or about $0.5 \mathrm{~m}$ in that time. The dieback process involves winter killing by frost desiccation and abrasion by windblown snow and ice particles of the most exposed rim of plant cover, chiefly Empetrum. Subsequent erosion of this rim during spring and early summer is followed by dissipation of organic soils and the finer fractions of the top mineral soil by wind and rain action. In 1995, a small, prostrate, birch tree, growing $6.9 \mathrm{~m}$ outside the front (in Plot B), displayed 71 tree rings at the base. Conceivably, it became established and grew to tree size in intact vegetation well within the front (Fig. 4). It follows that, over less than 70 years, stand decline and erosion of ground cover and soil have proceeded by c. $7 \mathrm{~m}$ horizontally. Moreover, some roots from living trees extended 2-3 $\mathrm{m}$ into the deflation area of Plot B. Apparently, these data indicate that the entire sample plot has been denuded over the past century or so.

\section{Soil Temperatures and Snow Regimes}

During the period 1996-2004, maximum summer soil temperatures in Plot A, usually occurring in early August, ranged between $7.1^{\circ}$ and $10.8^{\circ} \mathrm{C}$. The years 2002 and 2003 displayed by far the highest records. Typically, freezing at the $25 \mathrm{~cm}$ level took place during December and thawing in the first half of June. The latter phenophase (and leaf unfolding) is one to two weeks later than in more sheltered and snow-rich birch stands at the same elevation. Minimum winter temperatures (early to mid March) varied over the years between $-0.5^{\circ}$ and $-1.6^{\circ} \mathrm{C}$. On a regional scale, the winters $1995-2003$ were milder than the reference normal (1961-90), but there is no obvious trend during this short period (Alexandersson, 2002). 
TABLE 1. Radiocarbon dates of subfossil birch remnants within Plot $\mathrm{B}$, listed according to the distance to the erosion front, i.e., the interface between Plots A and B.

\begin{tabular}{|c|c|c|}
\hline Laboratory No. & $\begin{array}{l}\text { Radiocarbon Age } \\
\qquad\left({ }^{14} \mathrm{C} \text { yr BP }\right)\end{array}$ & $\begin{array}{l}\text { Distance to the A/B Border } \\
\qquad(\mathrm{m})\end{array}$ \\
\hline Beta-5400 & Post 0 & 0.2 \\
\hline Beta-91501 & Post 0 & 0.2 \\
\hline Beta-91502 & Post 0 & 0.3 \\
\hline ST-13622 & $<250$ & 0.4 \\
\hline Beta-99189 & Post 0 & 0.5 \\
\hline Beta-99203 & Post 0 & 0.5 \\
\hline Beta-99410 & Post 0 & 0.7 \\
\hline ST-13616 & $<250$ & 0.9 \\
\hline Beta-99411 & Post 0 & 1.3 \\
\hline Beta-106350 & Post 0 & 1.4 \\
\hline Beta-106353 & Post 0 & 1.8 \\
\hline Beta-106356 & Post 0 & 2.6 \\
\hline Beta-108770 & Post 0 & 3.0 \\
\hline ST-13610 & $<250$ & 3.1 \\
\hline Beta-106354 & Post 0 & 3.4 \\
\hline Beta-99217 & $30 \pm 60$ & 3.5 \\
\hline Beta- 86972 & $10 \pm 70$ & 3.5 \\
\hline Beta-99192 & $40 \pm 50$ & 3.9 \\
\hline Beta-99413 & $80 \pm 60$ & 4.1 \\
\hline Beta-160728 & $50 \pm 60$ & 5.0 \\
\hline Beta-99212 & $70 \pm 60$ & 5.2 \\
\hline Beta-106355 & $90 \pm 80$ & 5.3 \\
\hline Beta-106358 & $90 \pm 50$ & 5.8 \\
\hline Beta-99193 & $110 \pm 60$ & 6.4 \\
\hline ST-13628 & $<250$ & 7.1 \\
\hline Beta-91500 & $110 \pm 50$ & 7.5 \\
\hline ST-13610 & $<250$ & 8.0 \\
\hline Beta-91499 & $240 \pm 50$ & 8.1 \\
\hline ST-13620 & $<250$ & 8.2 \\
\hline ST-13617 & $<250$ & 8.9 \\
\hline Beta-99407 & $140 \pm 50$ & 9.1 \\
\hline Beta-99409 & $160 \pm 80$ & 9.2 \\
\hline ST-13615 & $<250$ & 9.3 \\
\hline Beta-180209 & $150 \pm 60$ & 9.3 \\
\hline Beta-106377 & $230 \pm 60$ & 9.5 \\
\hline ST-13607 & $<250$ & 9.6 \\
\hline ST-13614 & $<250$ & 9.8 \\
\hline
\end{tabular}

Strong wind exposure implies that the snow cover has been thin or periodically absent during the winter in both Plot A and Plot B. Within Plot A, the maximum snow depth, usually occurring in March, is about $15-20 \mathrm{~cm}$. Plot B used to be snow-free or lightly dusted. Occasionally, the ground in Plot B is covered with a more or less well-developed ice crust. Evidence seen during casual observations in spring (April-May) indicates that the soil surface in this plot is subjected to strong diurnal freeze/ thaw cycles. In plot $\mathrm{C}$, a deep snow pack ( $>2 \mathrm{~m}$ ) accumulates during the winter and usually remains until after midJune.

\section{Birch Age Structure within Plot C}

Most birches within the plot are multi-stemmed individuals, and therefore the age structure is based on more than one stem for each individual (Fig. 5). The oldest living stems date back to the late 19th century. The presence of a few decaying stumps from prior stout trees suggests that the population has a longer continuity than

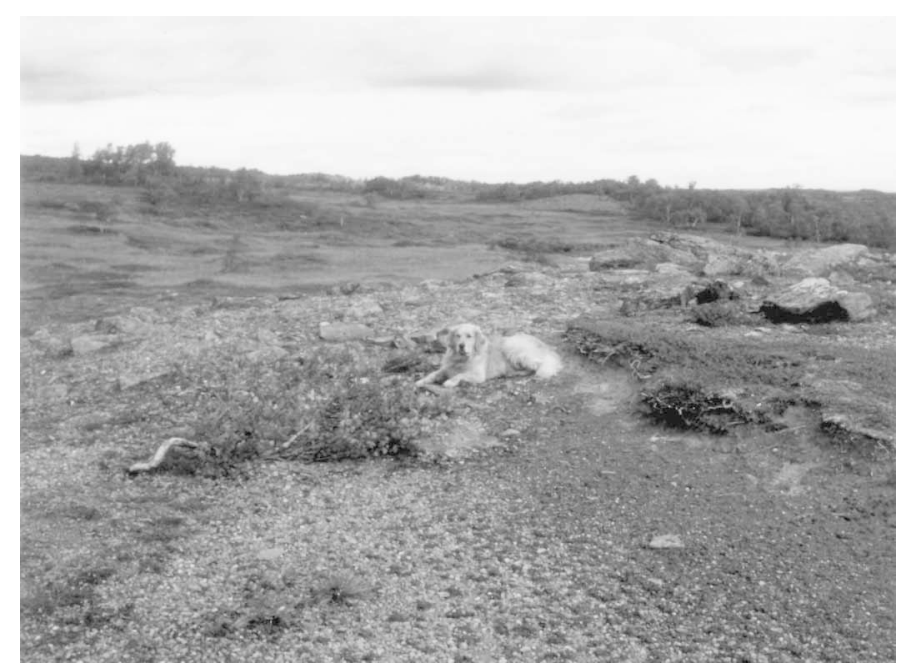

FIG. 4. Prostrate 71-year-old birch tree growing about $7 \mathrm{~m}$ outside the erosion front that indicates the rate of horizontal vegetation and soil stripping.

that, although the prevalence of young and tiny stems suggests that stand density has increased substantially during the past century. The presence of quite tall and declining specimens of light-demanding Juniperus communis also indicates a former more open structure.

Regeneration, both establishment of new individuals from seed and emergence of new basal sprouts, peaked in the 1930s and then declined over the following decades until a resurgence took place in the 1990s. In addition, virtual absence $(<1 \%)$ of dead standing stems lends this stand a vital and expansive appearance, which is further enhanced by exceptionally long top-shoots $(20-30 \mathrm{~cm})$ during the years 2002 and 2003.

\section{DISCUSSION}

Since 1972, the birch population in Plot A has declined by $60 \%$ in living height. In addition, the substantial individual mortality (30\%) is not balanced by any recruitment of new birch individuals. At this rate, this birch stand could become entirely exterminated well before the close of the present century. Much earlier, the residual population will be reduced to an assemblage of tiny basal sprouts emerging from the decaying stumps of previously tree-sized stems. As the size of the birches and the density of the stand diminish, wind shelter and snow retention are likely to decrease substantially (cf. Hiemstra et al., 2002). In addition, as the ground becomes increasingly smooth and level through wind erosion of the ground cover and organic top soil, the potential for intraspecific, interspecific, and microsite facilitation decreases, and birch establishment is prohibited (cf. Smith et al., 2003). Taken together, these circumstances may trigger a feedback loop that speeds up complete demise.

The lack of seed regeneration is not likely to be a consequence of poor seed viability in the treeline ecotone. On the contrary, this quality has improved substantially 


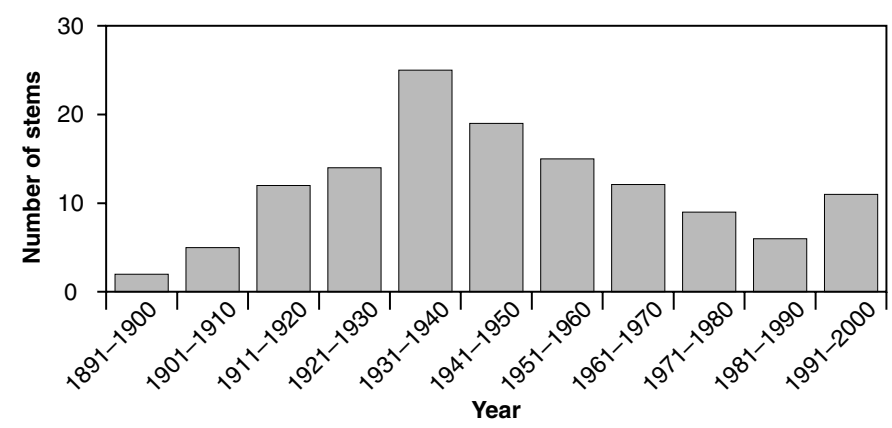

FIG. 5. Age structure (10-year classes) of the birch population in Plot $\mathrm{C}(\mathrm{n}=$ 130). All stems taller than $1 \mathrm{~m}$ were aged.

over the past 15 years in the study area (Kullman, 2004c). Moreover, mountain birch is currently regenerating quite freely in more sheltered sites with ample soil moisture, even high above the current treeline (Kullman, 2002, $2004 \mathrm{a}, \mathrm{c})$. Thus, the regeneration process does not seem to be constrained by insufficient heat. Instead, failure to regenerate is more likely to result from soil moisture and nutrient deficiency within this highly wind-exposed setting. The site is largely deprived of finer soil fractions and has a tendency, further aggravated by the erosion process, to dry out early in the summer. The sensitivity of mountain birch seedlings to soil drought and nitrogen deficiency has been well established experimentally (Kullman, 1984; Karlsson and Weih, 2001). A landscape-scale manifestation of this relationship is provided by the 20th-century history of the birch treeline in this region (Kullman, 1979). It was found that snow deflation sites with consequent and enhanced shortage of meltwater supply during the summer did not display upshifts of the treeline in response to the climatic warming trend. In addition, the recorded minute snow cover protection, associated low soil winter temperatures, and frequent freeze-thaw cycles during spring and autumn enhance the hostility of this environment with respect to establishment and survival of birch seedlings. Environmental conditions of this kind may be particularly damaging to fine roots of seedlings and saplings trying to establish here (cf. Holtmeier, 2000). Against this background, the general trend of decreasing soil moisture (see above) may have contributed to the birch demise in this particularly drought-prone setting.

Reindeer grazing and trampling are another potential obstacle to regeneration and an initiator of soil erosion, since these snow-poor sites are the only grazing grounds during the spring (Rudberg, 1968; Kullman, 1997; Öberg, 2002). However, reindeer are ancient and integral parts of this ecosystem, and the size of the herds has not changed significantly over the past century. A thorough review of existing data from the Swedish Mountains provides no evidence of large-scale or severe vegetation degradation or soil erosion during the past few decades that can be attributed to reindeer husbandry (Moen and Danell, 2003). Thus, reindeer activity is not likely to be the driving force behind the birch forest demise studied here. Although scarification and removal of vegetation and soil by rein- deer action in windward positions may have contributed to initiating the process in the distant past, its progression seems to depend primarily on the extreme character of the local climate, especially the wind. Certain support for the contention of reindeer disturbance as the triggering agent is provided by Smith (1920), who documented extensive destruction of exposed lichen heath in obvious response to grazing and trampling of anomalously large reindeer herds in this area during the first decade of the 20th century. Similar observations were reported a few years earlier (Sernander, 1905). Other potential initiators have been considered, such as outbreaks of defoliating insects, or the "fir wave" dieback phenomena observed in North America (e.g., Reiners and Lang, 1979). The first option is not supported by any observations reported in older descriptive accounts from this local area (Sernander, 1899; Smith, 1920; Tenow, 1972). The "fir wave" option is even less likely, since there is no regrowth behind the dying front to indicate cyclicity, and the resulting open spaces do not move over the hill slopes. Initial, catastrophic wind throw events are out of question, since practically all dated birch remnants are rooted in situ. A strong case for broad-scale causation mechanisms for the initiation and continuation (not the same) of the birch dieback is provided by the prevalence of the phenomenon described here in similar topographical situations, both nearby and elsewhere in northern Fennoscandia (see Introduction).

Conceivably, initiation is some kind of radical physical disturbance, and the balance of evidence suggests that reindeer action may have triggered the birch decline. Holtmeier et al. (2004) arrived at a similar conclusion with respect to the same type of processes in Finnish Lapland.

Since climate warming over the past century has not reversed the retrogressional trend of the birch at the study site, it must be inferred that particular local topoclimatic characteristics, wind exposure being the foremost, limit the studied birch population and its response patterns. The latter contention is strongly supported by the progressive and contrasting performance of the birch population in the nearby and much more sheltered Plot C.

It appears that the entire system in Plot A is rapidly approaching a stage where it will be pushed over its threshold of recovery. This is obviously what happened in Plot B, where a birch population similar to that currently existing in Plot A gradually died over 100 years or somewhat more-a period encompassing the close of the Little Ice Age cold episode (Grove, 1988) and the subsequent 20 th century warming phase (Alexandersson, 2002). Analyses of long-term instrumental meteorological data reveal that the latter course of climate evolution in Scandinavia has been associated with a strong increase in westerly atmospheric circulation (Jönsson and Fortuniak, 1995; Alexandersson et al., 2000; Omstedt et al., 2004). The higher frequency of strong westerly winds, in combination with earlier snowmelt (Moberg et al., 2005), may have aggravated site conditions for birch, particularly at westexposed sites like the one focused on here. This aspect 
should not be overstated, however, and it may well be that progressive birch decline has its roots in the Neoglacial climate cooling and associated treeline depression (Kullman, 1997, 2003; Holtmeier et al., 2004). After initial disturbance, possibly by reindeer, during this period, the process may have proceeded more or less autogenically in the most exposed sites, which strongly indicates the crucial importance of wind for treeline performance.

Conceivably, birch demise will stop as the front passes eastwards over the crest of the hillock at the upper (western) fringe of Plot C, where wind shelter and snow accumulation increase dramatically within a very short distance. Furthermore, birch growth here is likely to benefit from steady nutrient enrichment from the eroding soil, which is redeposited on this lee side (cf. Malanson and Butler, 1994).

The present results highlight complex interactions between climate and the heterogeneous physical landscape, which govern treelines and their responses to climate change (cf. Kupfer and Cairns, 1996; Holtmeier, 2000; Kullman, 2001; Malanson, 2001; Kjällgren and Kullman, 2002). These insights add to the rising uncertainty concerning direction and magnitude of treeline changes in a hypothetical warmer world (cf. Grishin, 1995; Risser, 1995; Crawford et al., 2003; Moore, 2003). Modeling of the development of the high-elevation arboreal landscape in a virtually unprecedented future climatic regime (IPCC, 2001) has to consider the local operation of mechanisms such as the one uncovered in the present study. Moreover, as potential tree limits rise towards higher and generally windier environments, accounting for the current type of counteractive mechanisms could reasonably become increasingly relevant (cf. Grace, 1997). This point is further substantiated since anticipated "greenhouse warming" may be associated with an even higher frequency of strong westerly winds (Davis, 1989; Andersen et al., 2001).

The present study strengthens the view that wind is an important and generally underrated ecological disturbance factor and modulator of local treeline patterns and positions (cf. Reiners and Lang, 1979; Davis, 1989; Grace, 1989; Komárková and Wielgolaski, 1999; Seppälä, 2004). For that reason, consistent climate warming will not evoke broad frontal displacement of vegetation belts at a common rate to increasingly higher altitudes (cf. Woodward, 1993). Primarily, expansion of subalpine forest vegetation will be patchily restricted to sheltered slopes with ample soil moisture, while it will proceed much more slowly (if at all) on wind-open, exposed sites. This scenario is analogous to tree-limit performance during the warm and dry early Holocene, when trees grew in isolated, sheltered patches 500-600 m above their current limits (Kullman, 2004b). Regional response patterns recorded empirically over the past century further support that contention, showing that the magnitude of climate-driven treeline advance relates to the degree of wind exposure and associated ecological conditions (Kullman, 1979).

\section{ACKNOWLEDGEMENTS}

This study was funded by the Swedish Research Council. Thanks are due to Anna-Karin Kullman for assistance in the field. I am most grateful to anonymous referees, who contributed to the clarity of the paper.

\section{REFERENCES}

ALEXANDERSSON, H. 2002. Temperatur och nederbörd i Sverige 1860-2001. SMHI Meteorologi 10:1-28.

ALEXANDERSSON, H., TUOMENVIRTA, H., SCHMITH, T., and IDEN, K. 2000. Trends of storms in Europe derived from an updated pressure data set. Climate Research 14:71-73.

ANDERSEN, U.J., KAAS, E., and MAY, W. 2001. Changes in the storm climate in North Atlantic/European region as simulated by GCM time-slice experiments at high resolution. Danish Climate Centre Report No. 01-1. Copenhagen: Danish Meteorological Institute.

BUTLER, D.R., and DECHANO, L.M. 2001. Environmental change in Glacier National Park, Montana: An assessment through repeat photography from fire lookouts. Physical Geography 22:291-304.

CRAWFORD, R.M.M., JEFFREE, C.E., and REES, W.G. 2003. Paludification and forest retreat in northern oceanic environments. Annals of Botany 91:213-226.

DAVIS, M.B. 1989. Insight from paleoecology on global change. Bulletin of the Ecological Society of America 20:222-228.

GRACE, J. 1989. Tree lines. Philosophical Transactions of the Royal Society of London, Series B 324:233-245.

-1997. The oceanic tree-line and the limit for tree growth in Scotland. Botanical Journal of Scotland 49:223-236.

GRACE, J., BERNINGER, F., and NAGY, L. 2002. Impacts of climate change on the treeline. Annals of Botany 90:537-544.

GRISHIN, S.Y. 1995. The boreal forests of north-eastern Eurasia. Vegetatio 121:11-21.

GRISHIN, S.Y., DEL MORAL, R., KRESTOV, P.V., and VERKHOLAT, V.P. 1996. Succession following the catastrophic eruption of Ksudach volcano (Kamchatka, 1907). Vegetatio 127:129-153.

GROVE, J.M. 1988. The Little Ice Age. New York: Methuen.

HARRIS, S.A. 2001. Twenty years of data on climate-permafrostactive layer variations at the lower limit of alpine permafrost, Marmot Basin, Jasper National Park, Canada. Geografiska Annaler 83A:1-14.

HIEMSTRA, C.A., LISTON, G.E., and REINERS, W.A. 2002. Snow redistribution by wind and interactions with vegetation at upper treeline in the Medicine Bow Mountains, Wyoming, U.S.A. Arctic, Antarctic, and Alpine Research 34:262-273.

HOLTMEIER, F.-K. 2000. Die Höhengrenze der Gebirgswälder. Arbeiten aus dem Institut für Landschaftsökologie Westfälische Wilhelms-Universität $8.337 \mathrm{p}$.

HOLTMEIER, F.-K., BROLL, G., MÜTERTHIES, A., and ANSCHLAG, K. 2003. Regeneration of trees in the treeline ecotone: Northern Finnish Lapland. Fennia 181:103-128. 
HOLTMEIER, F.-K., BROLL, G., and ANSCHLAG, K. 2004. Winderosion und ihre Folgen im Waldgrenzbereich und in der alpinen Stufe einiger Nordfinnischer Fjelle. Geoöko 25: 203-224.

IPCC (INTERGOVERNMENTAL PANEL ON CLIMATE CHANGE). 2001. Climate change 2001: The scientific basis. Cambridge: Cambridge University Press.

JÖNSSON, P., and FORTUNIAK, K. 1995. Interdecadal variations of surface wind direction in Lund, southern Sweden, 17411990. International Journal of Climatology 15:447-461.

KARLSSON, P.S., and WEIH, M. 2001. Soil temperatures near the distribution limits of the mountain birch: Implications for seedling nitrogen economy and survival. Arctic, Antarctic, and Alpine Research 33:88-92.

KJÄLLGREN, L., and KULLMAN, L. 2002. Geographical patterns of tree-limits of Norway spruce and Scots pine in the southern Swedish Scandes. Norwegian Journal of Geography 56: 237-245.

KOMÁROKOVÁ, V., and WIELGOLASKI, F.E. 1999. Stress and disturbance in cold region ecosystems. In: Walter, L.R., ed. Ecosystems of disturbed ground. Amsterdam: Elsevier. 39-122.

KREMENETSKI, C., VASCHALOVA, T., and SULERZHITSKY,

L. 1999. The Holocene vegetation history of the Khibiny Mountains: Implications for the post-glacial expansion of spruce and alder on the Kola Peninsula, northwestern Russia. Journal of Quaternary Science 14:29-43.

KULLMAN, L. 1979. Change and stability in the altitude of the birch tree-limit in the southern Swedish Scandes. Acta Phytogeographica Suecica 65. $121 \mathrm{p}$.

-1984. Transplantation experiments with saplings of Betula pubescens ssp. tortuosa near the tree-limit in central Sweden. Holarctic Ecology 7:289-293.

_ 1997. Tree-limit stress and disturbance: A 25-year survey of geoecological change in the Scandes Mountains of Sweden. Geografiska Annaler 79A:139-165.

- 2001. 20th century climate warming trend and tree-limit rise in the southern Scandes of Sweden. Ambio 30:72-80.

- 2002. Rapid recent range-margin rise of tree and shrub species in the Swedish Scandes. Journal of Ecology 90:68-77.

- 2003. Recent reversal of Neoglacial climate cooling trend in the Swedish Scandes as evidenced by mountain birch treelimit rise. Global and Planetary Change 3:77-88.

2004a. The changing face of the alpine world. Global Change Newsletter 57:12-14.

_. 2004b. Early Holocene appearance of mountain birch (Betula pubescens ssp.tortuosa) at unprecedented high elevations in the Swedish Scandes: Megafossil evidence exposed by recent snow and ice recession. Arctic, Antarctic, and Alpine Research 36: $172-180$.

- 2004c. A face of global warming: "Ice birches" and a changing alpine plant cover. Geoöko 25:181-202.

- 2004d. Tree-limit landscape evolution at the southern fringe of the Swedish Scandes (Dalarna province): Holocene and 20th century perspectives. Fennia 182(2):73-94.

KUPFER, J.A., and CAIRNS, D.M. 1996. The suitability of montane ecotones as indicators of global climatic change. Progress in Physical Geography 20:253-272.
LLOYD, A.H., and FASTIE, C.L. 2003. Recent changes in treeline forest distribution and structure in interior Alaska. Ecoscience 10:176-185.

LUNDQVIST, G. 1948. De svenska fjällens natur. Stockholm: Svenska Turistföreningens Förlag.

MALANSON, G.P. 2001. Complex responses to global change at alpine treeline. Physical Geography 22:333-342.

MALANSON, G.P., and BUTLER, D.R. 1994. Competitive hierarchies, soil fertility gradients, and the elevation of treeline in Glacier National Park, Montana. Physical Geography 15: $166-180$.

MEShineV, T., APOSTOlOVA, I., and KOLEVA, E. 2000. Influence of warming on timberline rising: A case study on Pinus peuce Griseb. in Bulgaria. Phytocoenologia 30:431 - 438.

MOBERG, A., TUOMENVIRTA, H., and NORDLI, Ö. 2005. Recent climatic trends. In: Seppälä, M., ed. The physical geography of Fennoscandia. Oxford: Oxford University Press. $113-133$.

MOEN, J., and DANELL, Ö. 2003. Reindeer in the Swedish mountains: An assessment of grazing impacts. Ambio 32: 397-402.

MOORE, P.D. 2003. Back to the future: Biogeographical responses to climate change. Progress in Physical Geography 27: $122-129$.

MUNROE, J.S. 2003. Estimates of Little Ice Age climate inferred through historical rephotography, northern Uinta Mountains, U.S.A. Arctic, Antarctic, and Alpine Research 35:489-498.

ÖBERG, L. 2002. Tree-limit dynamics on Mount Sånfjället. Svensk Botanisk Tidskrift 96:177-185.

OMSTEDT, A., PETTERSEN, C., RODHE, J., and WINSOR, P. 2004. Baltic Sea climate: $200 \mathrm{yr}$ of data on air temperature, sea level variation, ice cover, and atmospheric circulation. Climate Research 25:205-216.

RAAB, B., and VEDIN, H., eds. 1995. Climate, lakes and rivers. Höganäs: Bra Böcker.

RÄISÄNEN, J., HANSSON, U., ULLERSTIG, A., DÖSCHER, R., GRAHAM, L.P., JONES, C., MEIER, H.E.M., SAMUELSSON, P., and WILLÉN, U. 2004. European climate in the late twenty-first century: Regional simulations with two driving global models and two forcing scenarios. Climate Dynamics 22:13-31.

REINERS, W.A., and LANG, G.E. 1979. Vegetational patterns and processes in the balsam fir zone, White Mountains, New Hampshire. Ecology 60:403-417.

RISSER, P.G. 1995. The status of the science examining ecotones. BioScience 45:318-325.

ROBERTSON, A. 1993. Effects of wind on boreal forest. In: Alden, J., Mastrantonio, J.L., and Ødum, S., eds. Forest development in cold climate. New York: Plenum Press. 203-225.

RUDBERG, S. 1968. Wind erosion: Preparation of maps showing the direction of eroding winds. Biuletyn Peryglacjalny 17: $181-193$.

SEPPÄLÄ, M. 2004. Wind as a geomorphic agent in cold climates. Cambridge: Cambridge University Press.

SERNANDER, R. 1899. Studier öfver vegetationen i mellersta Skandinaviens fjälltrakter. Bihang till K. Svenska Vet.-Akad. Handlingar 24 (III): 1-56. 
1905. Flytjord i svenska fjälltrakter. Geologiska Föreningens i Stockholm Förhandlingar 232:42-84.

SMITH, H. 1920. Vegetationen och dess utvecklingshistoria i det centralsvenska högfjällsområdet. Uppsala: Almqvist \& Wiksell.

SMITH, W.K., GERMINO, M.J., HANCOCK, T.E., and JOHNSON, D.M. 2003. Another perspective on altitudinal limits of alpine timberlines. Tree Physiology 23:1101-1112.
STUIVER, M., and PEARSON, G. 1986. High-precision calibration of the radiocarbon time scale, AD 1950-500 B.C. Radiocarbon 28:805-838.

TENOW, O. 1972. The outbreaks of Oporinia autumnata Bkh. and Operophthera spp. (Lep., Geometridae) in the Scandinavian mountain chain and northern Finland 1862-1968. Zoologiska Bidrag från Uppsala, Supplement 2. 107 p.

WOODWARD, F.I. 1993. The lowland-to-upland transition: Modelling plant responses to environmental change. Ecological Applications 3:404-408. 